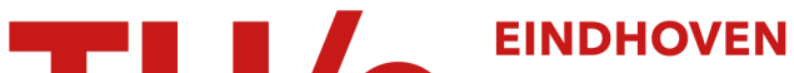 \\ UNIVERSITY OF \\ TECHNOLOGY
}

\section{Capillary electrophoretic separation of herbicidal enantiomers applying ergot alkaloids}

\section{Citation for published version (APA):}

Ingelse, B. A., Reijenga, J. C., Flieger, M., \& Everaerts, F. M. (1997). Capillary electrophoretic separation of herbicidal enantiomers applying ergot alkaloids. Journal of Chromatography, A, 791(1-2), 339-342. https://doi.org/10.1016/S0021-9673(97)00815-7

DOI:

10.1016/S0021-9673(97)00815-7

Document status and date:

Published: 01/01/1997

\section{Document Version:}

Publisher's PDF, also known as Version of Record (includes final page, issue and volume numbers)

\section{Please check the document version of this publication:}

- A submitted manuscript is the version of the article upon submission and before peer-review. There can be important differences between the submitted version and the official published version of record. People interested in the research are advised to contact the author for the final version of the publication, or visit the $\mathrm{DOI}$ to the publisher's website.

- The final author version and the galley proof are versions of the publication after peer review.

- The final published version features the final layout of the paper including the volume, issue and page numbers.

Link to publication

\section{General rights}

Copyright and moral rights for the publications made accessible in the public portal are retained by the authors and/or other copyright owners and it is a condition of accessing publications that users recognise and abide by the legal requirements associated with these rights.

- Users may download and print one copy of any publication from the public portal for the purpose of private study or research.

- You may not further distribute the material or use it for any profit-making activity or commercial gain

- You may freely distribute the URL identifying the publication in the public portal.

If the publication is distributed under the terms of Article $25 \mathrm{fa}$ of the Dutch Copyright Act, indicated by the "Taverne" license above, please follow below link for the End User Agreement:

www.tue.nl/taverne

Take down policy

If you believe that this document breaches copyright please contact us at:

openaccess@tue.nl

providing details and we will investigate your claim. 


\title{
Capillary electrophoretic separation of herbicidal enantiomers applying ergot alkaloids
}

\author{
Benno A. Ingelse ${ }^{\mathrm{a}, *}$, Jetse C. Reijenga ${ }^{\mathrm{a}}$, Mirko Flieger ${ }^{\mathrm{b}}$, Frans M. Everaerts ${ }^{\mathrm{a}}$ \\ ${ }^{a}$ Laboratory of Instrumental Analysis, Department of Chemistry, Eindhoven University of Technology, P.O. Box 513, \\ $5600 \mathrm{MB}$ Eindhoven, Netherlands \\ ${ }^{\mathrm{b}}$ Institute of Microbiology, Academy of Sciences of the Czech Republic, Videnská 1083, C-14220 Prague 4, Czech Republic
}

Received 2 June 1997; received in revised form 28 July 1997; accepted 28 July 1997

\begin{abstract}
The capillary electrophoretic separation of some herbicidal enantiomers is shown applying 1-allylterguride as chiral selector. Baseline separation is shown for the enantiomers of fluazifop, halossifop and fenoxaprop, whereas the optical isomers of flamprop could be partially resolved. Separation times are short compared to similar analyses, applying HPLC and a terguride chiral stationary phase. The degree of dissociation of the acidic analytes, as well as the amount of methanol present in the background electrolyte, are shown to have a major influence on enantioresolution, as expected form earlier studies. (ㅇ 1997 Elsevier Science B.V.
\end{abstract}

Keywords: Enantiomer separation; Ergot alkaloids; Alkaloids; Fluazifop; Halossifop; Fenoxaprop; Flamprop

\section{Introduction}

The introduction of automated equipment for capillary zone electrophoresis (CZE), applying fused-silica capillaries, in the early 1980s has strongly increased the number of applications of CZE. Chiral analysis has become one of the main areas of interest, resulting in some detailed reviews, listing many applications and hundreds of references [1-3]

Chloro-2-phenoxypropionic (Cl-APA) and halogen substituted 2-aryloxyphenoxy-propionic (APPA) acids, as well as N-benzoyl-N-(3-chloro-4-flurophenyl)amino-propionic acid (flamprop) are (structurally related to) herbicides. These compounds have a stereocenter in position 2 of the propionic acid functional group. It has been shown that the $(R)-(-)-$

${ }^{*}$ Corresponding author. isomers of Cl-APAs and APPAs, and the $(R)-(+)$ isomer of flamprop exhibit the strongest herbicidal activity [4-6]. However, both optical isomers of these compounds are toxic [7], and their use should therefore be minimized. Consequently, recent legislation in several European countries has resulted in the marketing of pure enantiomers. Analytical methods are needed in order to determine the optical purity of these formulations. Liquid chromatography, using a Pirkle-type chiral stationary phase (CSP) can be applied for the above purpose [5,7]. The capillary electrophoretic separation of phenoxy acid herbicide enantiomers, applying $\alpha-\mathrm{CD}$ and DIME- $\beta$ as chiral selector, was shown by Nielen [8]. Recently, Padiglioni et al. showed the enantioseparation of some herbicides applying a CSP derived from terguride [9].

Earlier, this terguride CSP showed high selec- 
tivities for the enantiomers of several organic acids [10]. In recent studies [11,12] we have shown the applicability of terguride and structurally related compounds, as chiral selectors in CE. In this study, $\mathrm{CE}$ using the 1-allyl derivative of $(5 R, 8 S, 10 R)$-terguride (allyl-TER) as chiral selector was applied for the chiral separation of some herbicidal compounds. The same analytes as those used in the HPLC study [9] were chosen in order to make a fair comparison between both separation techniques.

\section{Experimental}

A P/ACE 2200 (Beckman, Fullerton, CA, USA) was used for all electrophoretic experiments. The instrument used uncoated and polyacrylamide coated capillaries [13] of $37 \mathrm{~cm}$, with an effective length of $30 \mathrm{~cm}$ and an I.D. of $50 \mu \mathrm{m}$. The UV detector was operated at $230 \mathrm{~nm}$. The applied voltage was $20 \mathrm{kV}$ or $30 \mathrm{kV}$. The capillary cartridge was thermostated at $25^{\circ} \mathrm{C}$.

$\beta$-Alanine and acetic acid were purchased from Merck (Darmstadt, Germany). Allyl-TER was synthesized by a previously published method [14]. Fluazifop (2-(4-\{[5-(trifluoromethyl)-2-pyridinyl $]$ oxy\}-phenoxy)propionic acid), halossifop (2-(4-\{[3chloro- 5 -(trifluoromethyl)- 2 -pyridinyl]oxy\}phenoxy)propionic acid), fenoxaprop (2-[4-(6-chloro-2-benzoxazolyl)oxy]phenoxypropionic acid) and flamprop (N-benzoyl-N-(3-chloro-4 fluorophenyl)-DL-alanine<smiles>CC(Oc1ccc(Oc2ccc(C(F)(F)F)cn2)cc1)C(=O)O</smiles>

Fluazifop

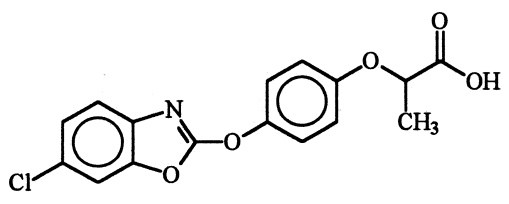

Fenoxaprop were donated by the Istituto di Cromatografia (CNR, Rome, Italy). The structure of these compounds is shown in Fig. 1.

All samples were dissolved in $\mathrm{MeOH}-\mathrm{H}_{2} \mathrm{O}$ (1:5) to a concentration of $10^{-4} \mathrm{M}$ and injected hydrodynamically $\left(5 \mathrm{~s}, 3 \cdot 10^{3} \mathrm{~Pa}\right)$. The BGE was prepared by adjusting a $200 \mathrm{~m} M \quad \beta$-alanine solution with acetic acid to $\mathrm{pH}$ 4.0. Subsequently, 1 part of this electrolyte solution was diluted with 1 part of $\mathrm{MeOH}$. This resulted in a BGE consisting of 100 $\mathrm{m} M \beta$-alanine-acetate, $50 \% \mathrm{MeOH}(\mathrm{pH} 5.3$ ).

\section{Results and discussion}

According to the literature, a phenoxy substituent at the $\alpha$-position of propionic acid decreases the $\mathrm{p} K_{\mathrm{a}}$ value of the analyte from 4.9 to 3.1 [15]. Therefore, it can be assumed that fluazifop, halossifop, and fenoxaprop have a high degree of dissociation, whereas flamprop is assumed to have a relatively low degree of dissociation, at the selected $\mathrm{pH}$ value. This is confirmed by the migration behavior, where no chiral selector was added to the BGE. The phenoxy substituted analytes pass the detection window well within $9 \mathrm{~min}$ in the order of their molecular masses $\left(M_{\mathrm{r}}\right)$ (1st fluazifop; $M_{\mathrm{r}}=327,2 \mathrm{nd}$ fenoxaprop; $M_{\mathrm{r}}=$ 333.5, 3rd halossifop; $M_{\mathrm{r}}=361.5$ ), whereas flamprop $\left(M_{\mathrm{r}}=321.5\right)$ passes the detection window after approximately $12 \mathrm{~min}$.

In order to separate the optical isomers of the<smiles>CC(Oc1ccc(Oc2ncc(C(F)(F)F)cc2Cl)cc1)C(=O)O</smiles><smiles>CC(C(=O)O)N(C(=O)c1ccccc1)c1ccc(F)c(Cl)c1</smiles>

Flamprop

Fig. 1. Chemical structures of the examined herbicides. 
herbicidal analytes, the buffer was supported with 25 $\mathrm{m} M$ allyl-TER, which resulted in a slight increase of the $\mathrm{pH}$ of the BGE. Before injecting the racemic analytes, the capillary was rinsed with BGE containing allyl-TER. The in- and outlet consisted of pure BGE, without chiral selector. The boundary between the zones with and without allyl-TER has self-sharpening properties, following the Kohlrausch regulation function. The properties of this boundary have been extensively discussed elsewhere $[12,16]$. In the electropherogram shown in Fig. 2, the boundary, which is migrating in the direction of the anode, passes the detection window after approximately 2.5 $\min$.

An electropherogram of the separation of the optical isomers of the herbicidal compounds is shown in Fig. 2. The enantiomers of the phenoxy substituted propionic acids are well separated in approximately $13 \mathrm{~min}$. No resolution was observed for the flamprop enantiomers. A possible explanation of the limited enantioselectivity of allyl-TER towards flamprop is the lower degree of dissociation of this compound. In recent studies, it is shown that only the dissociated acids interact stereoselective with the chiral selector [12,17].

An impurity, originating from the fenoxaprop

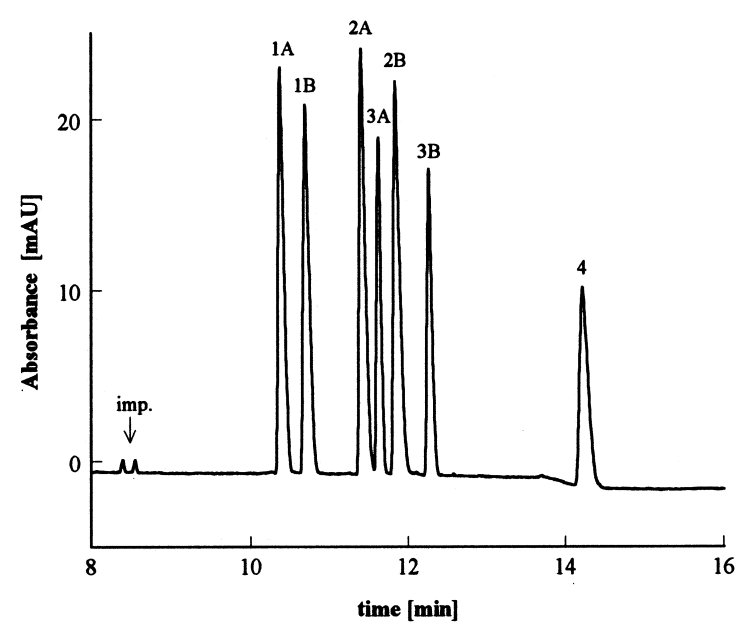

Fig. 2. Electropherogram of the chiral separation of some herbicidal compounds. $1 \mathrm{~A}, 1 \mathrm{~B}=$ fluazifop; $2 \mathrm{~A}, 2 \mathrm{~B}$ =halossifop; $3 \mathrm{~A}$, $3 \mathrm{~B}=$ fenoxaprop; 4=flamprop; imp.=impurity. BGE: $100 \mathrm{mM}$ $\beta$-alanine-acetate, $50 \% \mathrm{MeOH}(\mathrm{pH} 5.3$ ) supported with $25 \mathrm{mM}$ allyl-TER. Separation voltage $30 \mathrm{kV}$. Coated capillary: 30-37 $\mathrm{cm} \times 50 \mu \mathrm{m}$ I.D. sample, is visible as two small peaks after approximately $8 \mathrm{~min}$. The impurity seems to be a racemate since only one small peak is visible without the addition of the chiral selector to the BGE. It is possibly a degradation product of fenoxaprop: $2-\left(4^{\prime}-\right.$ hydroxyphenoxy)propanoic acid.

Partial resolution of flamprop enantiomers can be obtained by increasing the concentration of the chiral selector or by increasing the degree of dissociation of the analyte. Therefore, a BGE was applied consisting of pure $\mathrm{MeOH}$ containing $100 \mathrm{~m} M$ acetic acid and $50 \mathrm{~m} M$ triethanolamine (TEA), supported with 100 $\mathrm{m} M$ allyl-TER. Approximately the first $28 \mathrm{~cm}$ of an uncoated capillary were filled with BGE containing the chiral selector. The rest of the capillary, including the in- and the outlet vial contained $100 \mathrm{mM}$ acetate and $50 \mathrm{~m} M$ TEA in $100 \% \mathrm{MeOH}$. No migration of the boundary between the zones with and without allyl-TER was observed under these experimental conditions. Apparently, the electrophoretic mobility of the ergot alkaloid is largely compensated by the residual electroosmotic flow. The latter was reversed due to the presence of TEA in the BGE. The resulting electropherogram, applying 20 $\mathrm{kV}$, is shown in Fig. 3. Partial resolution is obtained for the enantiomers of flamprop $\left(R_{s}=0.7\right)$, whereas high resolutions were obtained for the optical isomers of the other compounds.

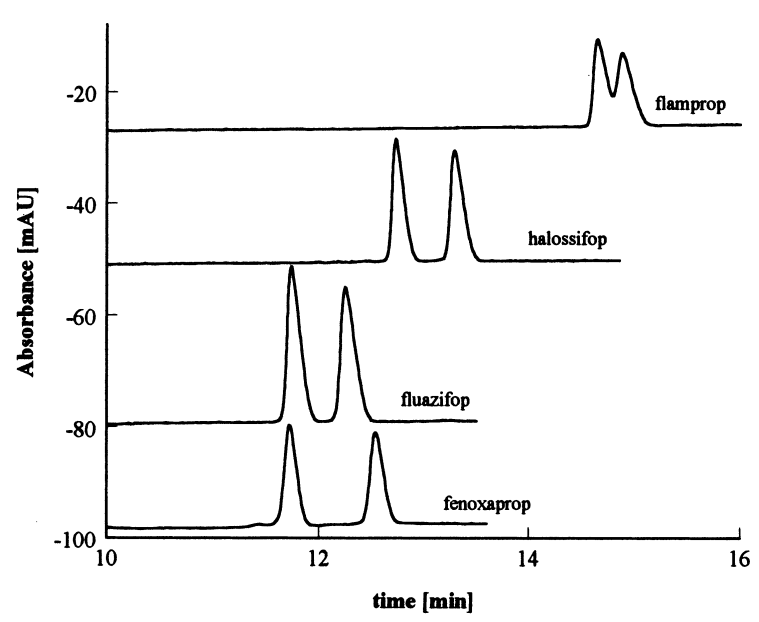

Fig. 3. Electropherogram of the chiral separation of some herbicidal compounds. BGE: $100 \mathrm{~m} M$ acetate, $50 \mathrm{~m} M$ TEA in $100 \%$ $\mathrm{MeOH}$ supported with $100 \mathrm{~m} M$ allyl-TER. Separation voltage 20 $\mathrm{kV}$. Uncoated capillary: $30-37 \mathrm{~cm} \times 50 \mu \mathrm{m}$ I.D. 
Similar resolutions as shown in Fig. 3 could be obtained applying HPLC [9]. The selectivities obtained in the HPLC experiments (as defined by $k_{1}^{\prime} /$ $k_{2}^{\prime}$ ) however, were much higher than those obtained in the CE experiments (as defined by the ratio of the effective mobilities of the optical isomers). Equal resolutions must be explained by the much higher efficiencies, usually obtained in CE. The separation time in CE is shorter than in HPLC; e.g., separation of the phenoxy substituted enantiomers takes approximately $90 \mathrm{~min}$, using the terguride packing in HPLC whereas only $15 \mathrm{~min}$ are needed applying CE with allyl-TER as chiral buffer additive (see Fig. 3).

In this study it is shown that CE can be successfully applied for the separation of the herbicidal optical isomers. The method can be useful for the analysis of real production samples and the determination of their enantiopurity.

\section{References}

[1] H. Nishi, S. Terabe, J. Chromatogr. A 694 (1995) 245.

[2] H. Nishi, J. Chromatogr. A 735 (1996) 57.
[3] S. Fanali, J. Chromatogr. A 735 (1996) 77.

[4] B. Blessington, N. Grabb, J. Chromatogr. 454 (1988) 450.

[5] W.A. Koning, D. Ichein, T. Runge, B. Pfaffenberg, P. Ludwig, H. Huhnerfuss, J. High Resolut. Chromatogr. 14 (1991) 530.

[6] D.W. Bewick, Pest. Sci. 17 (1986) 349.

[7] B. Blessington, N. Crabb, J. O’Sullivan, J. Chromatogr. 396 (1987) 177.

[8] M.W.F. Nielen, J. Chromatogr. 637 (1993) 81.

[9] P. Padiglioni, C.M. Polcaro, S. Marchese, M. Sinibaldi, M. Flieger, J. Chromatogr. A 756 (1996) 119.

[10] M. Sinibaldi, M. Flieger, L. Cvak, A. Messina, A. Pichini, J. Chromatogr. A 666 (1994) 471.

[11] B.A. Ingelse, J.C. Reijenga, H.A. Claessens, F.M. Everaerts, J. High Resolut. Chromatogr. 19 (1996) 225-226.

[12] B.A. Ingelse, M. Flieger, H.A. Claessens, F.M. Everaerts, J. Chromatogr. A 755 (1996) 251-260.

[13] M.J. van der Schans, J.L. Beckers, M.C. Molling, F.M. Everaerts, J. Chromatogr. A 717 (1995) 139.

[14] A. Messina, A.M. Girelli, M. Flieger, P. Sedmera, M. Sinibaldi, L. Cvak, Anal. Chem. 68 (1996) 1191.

[15] H.A. Sober (Ed.), Handbook of Biochemistry, 2nd ed., CRC, Cleveland, 1970.

[16] Benno A. Ingelse, Thesis, Eindhoven University of Technology, Eindhoven, 1997.

[17] B.A. Ingelse, J.C. Reijenga, F.M. Everaerts, J. Chromatogr. A 772 (1997) 179-184. 